\title{
Age-Related Lymphocyte Subset Changes in the Peripheral Blood of Healthy Children - a Meta-Study
}

\author{
Ulrich Sack ${ }^{\mathrm{a}}$ Fee Gerling ${ }^{\mathrm{a}} \quad$ Attila Tárnok ${ }^{\mathrm{b}}$ \\ a Department for Clinical Immunology and Transfusion Medicine, \\ ${ }^{b}$ Department for Pediatric Cardiology, Cardiac Center Leipzig GmbH, University of Leipzig, Germany
}

\section{Key Words}

Flow cytometry $\cdot$ Immunophenotyping $\cdot$ Childhood Lymphocytes

\section{Summary}

Background: Immunophenotyping is an important diagnostic tool for decision making in various diseases. Although clinical interpretation relies on measurable aberrations of the patient's values from normal ranges, agedependent are rarely available. Materials and Methods: The present study is aimed to combine published data about normal values of peripheral blood lymphocyte subpopulations to describe age-dependent changes from the neonate to the adult. These values could serve in a better way as normal values in comparison to present ones. Furthermore, this investigation allows us to define valid data even for short periods in children's life and to investigate the influence of technical approaches, sample preparation, antibody selection, measurement equipment, and data analysis. Results: Development-related alterations of lymphocyte subset counts in children could be extracted from the pre-existing papers for diagnostic use. These results were mostly independent from gender, ethnic factors, procedure of sample collection, anticoagulation, pre-analytical procedures, time to workbench, applied method for immunophenotyping, staining procedure, selected monoclonal antibodies, technical devices, and software products. Conclusion: Our data indicate that previous normal values are not sufficiently precise for the interpretation of lymphocyte subsets in children. Mainly during the 1st year of life, count and subset distribution of Iymphocytes is different from that of adults. Therefore, a close meshed data set of normal values is required to guarantee adequate diagnostic interpretation.

\section{Schlüsselwörter}

Durchflusszytometrie · Immunphänotypisierung ·

Kindheit · Lymphozyten

\section{Zusammenfassung}

Hintergrund: Die zytometrische Phänotypisierung von lymphozytären Zellen des peripheren Bluts hat sich zu einem diagnostisch relevanten Verfahren bei zahlreichen Erkrankungen entwickelt. Allerdings ist die Interpretation von Befunden im Kindesalter dadurch erschwert, dass kaum verlässliche und zusammenfassende Normalwertstudien in diesem Bereich verfügbar sind. Material und Methoden: Das Ziel der vorliegenden Publikation war die Zusammenführung verfügbarer Publikationen, die Lymphozyten im peripheren Blut von gesunden Kindern beschreiben, zu einem in der Praxis nutzbaren Datensatz mit lymphozytären Normalwerten im Kindesalter. Neben der engmaschigen Zuordnung zu einzelnen Lebensjahren sollte zudem der Einfluss präanalytischer Rahmenbedingungen, Färbungen, Antikörper, technischer Plattformen und Auswerteverfahren untersucht werden. Ergebnisse: Wir konnten aus der verfügbaren Literatur einen konsistenten Datensatz zusammenführen. Dabei waren die meisten Befunde weitestgehend unabhängig vom Geschlecht, der ethnischen Herkunft, den präanalytischen Verfahren, den gewählten Protokollen der Probenbearbeitung und -auswertung und den verwendeten Softwareprodukten. Schlussfolgerung: Unsere Daten weisen darauf hin, dass bisherige Normalwerte nicht exakt genug waren, um insbesondere im 1. Lebensjahr zytometrische Daten korrekt zu interpretieren. Zudem konnten wir eine engmaschige Datenbasis zur Verwendung als altersabhängige Normalwertübersicht bereitstellen.

\begin{tabular}{ll}
\hline KARGER & @ 2007 S. Karger GmbH, Freiburg \\
$\begin{array}{l}\text { Fax +49 7614520714 } \\
\begin{array}{l}\text { E-mail Information@Karger.de } \\
\text { www.karger.com }\end{array}\end{array}$ & $\begin{array}{l}\text { Accessible online at: } \\
\text { www.karger.com/tmh }\end{array}$ \\
\end{tabular}

Prof. Dr. Ulrich Sack

Institut für Klinische Immunologie und Transfusionsmedizin

Medizinische Fakultät der Universität Leipzig

Johannisallee 30, 04103 Leipzig, Germany

Tel. +49 341 97-25506, Fax -39367

E-mail ulrich.sack@medizin.uni-leipzig.de 


\section{Introduction}

It is a well-known fact that developmental changes from the neonate to the adult massively influence the composition of peripheral blood leukocytes as well as that of the lymphocytes. Immunophenotyping is an important diagnostic tool for decision making in various diseases [1-6]. Typical examples are:

- diagnosis of immunodeficiencies [7],

- monitoring of systemic and chronic diseases [8-12],

- cellular diagnostics of allergy $[13,14]$,

- functional characterization of cells $[15,16]$,

- genetic investigation $[17,18]$,

- differential diagnosis of lymphocytosis [19],

- diagnosis of leukemia [5, 20-24],

- investigation of T-cell receptor expression in Kawasaki syndrome [25-26],

- investigation of pregnancy disturbances [27],

- quality control in hemotherapy [28-30].

Furthermore, there are several indications that are presently not so important for routine diagnostics [31].

Clinical decision making relies on measurable aberrations of the patient's values from the 'normal' [32-34]. In children correct decision making heavily depends on the availability of these normal ranges for the respective age groups. It is of great concern that until today no reliable data exist that take into account the age-dependent changes. In many cases for children the normal values used for diagnostics are based upon data of adults. There is only a handful of published studies that report the lymphocyte subset composition of children in different age groups. These studies have several drawbacks, making their application difficult in everyday clinical diagnostic settings:
- limited number of children enrolled,

- different age groups or a limited age range investigated,

- technical equipment, namely flow cytometers and software products,

- reagents including lysis and antibodies,

- different parameters analyzed,

- one- or two-platform technologies.

\section{Aim}

The present study is aimed to combine existing studies (as far as they were combinable) into a meta-study describing age-dependent changes from the neonate to the adult. These values could serve in a better way as normal values as present ones. Furthermore, this investigation allows us to define valid data even for short periods in children's life and to investigate the influences of technical approaches, sample preparation, antibody selection, measurement equipment, and data analysis.

\section{Materials and Methods}

The present work is a meta-analysis compiling data published earlier by others. For this study, we screened databases of all publications reporting of normal values in children. As the primary raw data were in most cases not at hand, all available data (single values and calculated values) were included. We tried to contact all authors of these publications in order to ask them for the primary data. Unfortunately, this was successful only in few cases. We included exclusively studies based on cytometry and staining with monoclonal antibodies (for more details on cytometry and applications in clinical diagnostics see [35]). Technical options such as isolation of lymphocytes prior to staining, simultaneous staining with multiple fluorescent dyes, or data analysis options were investigated for influence on data, but data from these studies were not excluded.

Table 1. Age-related lower and upper limits (calculated by mean \pm SD) of lymphocyte counts in the peripheral blood

\begin{tabular}{|c|c|c|c|c|c|c|c|c|c|c|}
\hline \multirow[t]{3}{*}{ Age } & \multicolumn{10}{|c|}{ Mean cell count, GPT/1 } \\
\hline & \multicolumn{2}{|c|}{$\mathrm{T}$ helper cells } & \multicolumn{2}{|c|}{ cytotoxic $\mathrm{T}$ cells } & \multicolumn{2}{|l|}{ T cells } & \multicolumn{2}{|l|}{ B cells } & \multicolumn{2}{|c|}{ NK cells } \\
\hline & $-1 \mathrm{SD}$ & $+1 \mathrm{SD}$ & $-1 \mathrm{SD}$ & $+1 \mathrm{SD}$ & $-1 \mathrm{SD}$ & $+1 \mathrm{SD}$ & $-1 \mathrm{SD}$ & $+1 \mathrm{SD}$ & $-1 \mathrm{SD}$ & $+1 \mathrm{SD}$ \\
\hline Newborn & 1.50 & 2.50 & 0.73 & 1.65 & 2.10 & 3.32 & 0.46 & 0.94 & 0.48 & 1.54 \\
\hline 1 month & 2.25 & 4.27 & 0.86 & 2.62 & 3.02 & 5.94 & 0.93 & 2.37 & 0.26 & 0.84 \\
\hline 3 months & 2.27 & 4.33 & 0.88 & 2.58 & 3.17 & 6.11 & 0.93 & 2.37 & 0.26 & 0.84 \\
\hline 6 months & 2.30 & 4.52 & 1.10 & 2.82 & 3.17 & 6.11 & 0.93 & 2.37 & 0.26 & 0.84 \\
\hline 1 year & 1.71 & 3.51 & 1.21 & 2.57 & 1.87 & 4.47 & 0.58 & 1.92 & 0.14 & 0.70 \\
\hline 2 years & 1.60 & 3.14 & 1.06 & 2.60 & 1.87 & 4.47 & 0.58 & 1.92 & 0.14 & 0.70 \\
\hline 3 years & 1.18 & 2.76 & 0.61 & 1.79 & 1.84 & 4.34 & 0.58 & 1.92 & 0.03 & 0.59 \\
\hline 4 years & 1.14 & 2.08 & 0.54 & 1.32 & 1.39 & 3.47 & 0.18 & 1.14 & 0.13 & 0.49 \\
\hline 5 years & 0.64 & 2.12 & 0.51 & 1.23 & 1.17 & 3.19 & 0.18 & 1.14 & 0.13 & 0.49 \\
\hline 6 years & 0.67 & 1.91 & 0.48 & 1.04 & 1.16 & 2.82 & 0.19 & 0.85 & 0.12 & 0.48 \\
\hline 8 years & 0.73 & 1.55 & 0.48 & 0.88 & 1.35 & 2.47 & 0.15 & 0.55 & 0.16 & 0.44 \\
\hline 10 years & 0.71 & 1.37 & 0.41 & 0.83 & 1.14 & 2.36 & 0.12 & 0.48 & 0.16 & 0.44 \\
\hline 12 years & 0.68 & 1.40 & 0.43 & 0.85 & 1.25 & 2.31 & 0.14 & 0.44 & 0.16 & 0.44 \\
\hline 14 years & 0.66 & 1.40 & 0.40 & 0.78 & 1.21 & 2.31 & 0.14 & 0.44 & 0.16 & 0.44 \\
\hline 16 years & 0.66 & 1.38 & 0.37 & 0.75 & 1.20 & 2.26 & 0.20 & 0.40 & 0.15 & 0.39 \\
\hline Adults & 0.70 & 1.10 & 0.50 & 0.90 & 1.10 & 1.70 & 0.70 & 1.10 & 0.20 & 0.40 \\
\hline
\end{tabular}




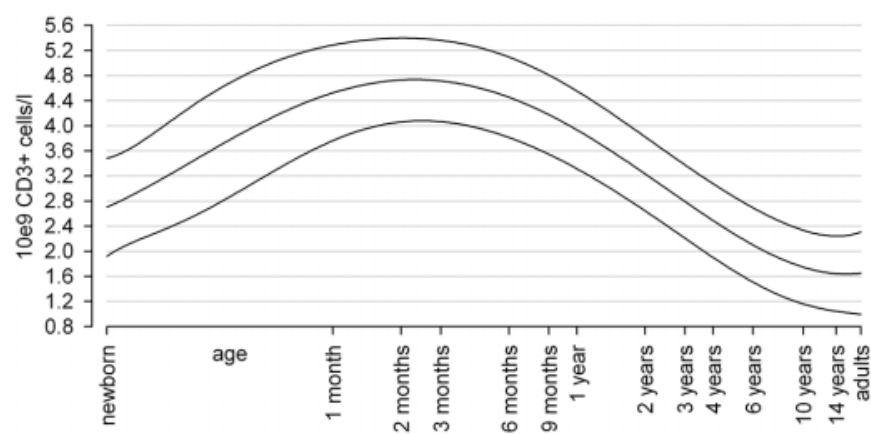

Fig. 1. T-cell count $(\mathrm{CD} 3+)$ in the peripheral blood of children from birth to adolescence. Lines represent mean and + or -1 SD. Calculation was based on 6 publications [36-41] and is in accordance with 7 available papers presenting median and percentiles [42-48].

Identification of References and Raw Data

We could identify 17 original publications describing lymphocyte subpopulations in children by flow cytometry. Most of these papers were found in citation databases, additional ones were identified by literature searches and in text books. In order to improve the database of normal values, we added further data out of our own laboratory.

We focused on the following lymphocyte populations:

- T cells $(\mathrm{CD} 3+)$,

- T helper cells (CD3+ CD4+ CD8-),

- cytotoxic T cells (CD3+ CD4- CD8+),

- B cells (CD19+),

- NK cells (CD16+ CD56 + CD3-).

Although a number of other subpopulations were described in several of these publications, we decided not to consider rarely reported findings. In 8 publications the data were reported as mean and standard deviation (SD). Such data were entered into the calculation of age-dependent normal values. This was not feasible for the other 9 papers that published data as median and percentiles, unless the raw data could be obtained from the authors.

\section{Data Collection}

Data were collected in tables and investigated by data analysis and comparison methods. In particular, the following data were taken into consideration:

- age, gender,

- sample collection, anticoagulation, pre-analytics, time to workbench,

- definition of normal group, ethnics,

- applied method for immunophenotyping, direct or indirect staining, monoclonal antibodies used,

- cell separation or whole blood protocols,

- instrumentation and software products,

- definition of cell populations, data analysis.

Statistic Analysis and Visual Presentation

Data analysis, statistical examination as well as definition of age-related values are based on calculation of patients' groups covering relevant age ranges. As a consequence of this approach, the patient's counts was initially reduced. However, it opened the opportunity to merge it with values from other studies that did not work with equal time spans. Thereby, mean values and standard deviations could be recalculated for these combined data. Non-parametric data were analyzed for fundamentally fitting values. It is noteworthy that there were no two studies that grouped the children into age groups of identical range.

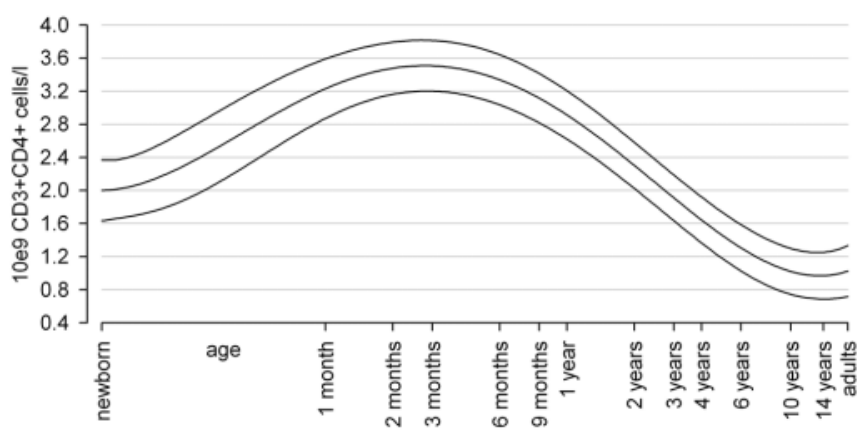

Fig. 2. Number of $\mathrm{T}$ helper cells $(\mathrm{CD} 3+\mathrm{CD} 4+\mathrm{CD} 8-)$ in the peripheral blood of children from birth to adolescence. Data represent mean and + or $-1 \mathrm{SD}$. Calculation was based on 6 publications $[37-41,49,50]$ and is in accordance with 7 available papers presenting median and percentiles $[42-46,51,52]$.

Data handling, statistical analysis, and graphic presentation were performed using SPSS 12 (SPSS Science, Erkrath, Germany) and SigmaPlot 10 (Systat, Erkrath, Germany).

\section{Results}

By help of the identified data we could generate a data set describing normal values in short time periods during childhood. Nearly all available publications could be included, except for selected ones. Data generated by the following methods were not included:

- analysis by cell sorters (such data did not fit with the other publications using flow cytometer analyzers)

- analysis by microscopic counting, and

- rosetting techniques instead of monoclonal antibodies.

All other data could be included into our study. We did not find any influence of the following variables on the results:

- gender,

- ethnicity,

- anticoagulant used,

- preparation of sample (ficoll vs. whole blood technology),

- monoclonal antibodies used,

- selected staining protocols,

- technical platform.

The results of the 16 included papers were statistically homogeneous. Cell counts are presented in the following figures. Table 1 shows the mean \pm 1 SD range for all investigated cell populations.

It was common for all lymphocyte subsets that there is a substantial dynamic change during the 1 st year of life. This finding is missing from previous publications because they are based on too long age ranges. Especially around the 4th to 6th month of life artificial T lymphocytosis could cause misinterpretation.

T-cell count during the 1st year of life was evidently higher than at older age. Especially during the second half of the 1st 


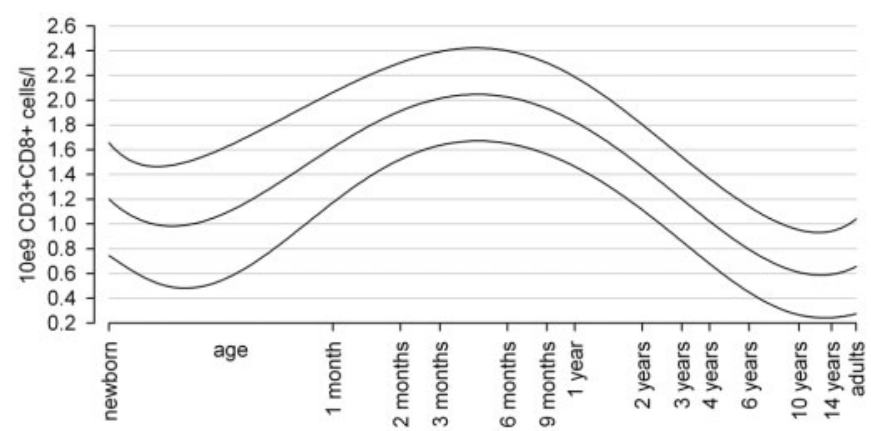

Fig. 3. Number of cytotoxic $\mathrm{T}$ cells $(\mathrm{CD} 3+\mathrm{CD} 4-\mathrm{CD} 8+)$ in the peripheral blood of children from birth to adolescence. Data represent mean and + or $-1 \mathrm{SD}$. Calculation was based on 7 publications $[37-41,49,50]$ and is in accordance with 7 available papers presenting median and percentiles $[42-46,51,52]$.

year of life, the number of $\mathrm{T}$ cells was higher then expected (fig. 1). Based on most accessible papers, there is a general consensus about this intermediate peak. All published data fit well with our own findings, but the common practice of classification of children into one '1st year group' sometimes obscures this fact and thereby causes underestimation of expected values.

$\mathrm{T}$ helper cell counts exhibited an intermediate peak around the 6th month of life, similar to that in T cells (fig. 2). All publications provided homogeneous findings, with a tendency to calculate too small $\mathrm{T}$ helper cell counts around the 6th month based on a long time period grouping of the enrolled children. Cytotoxic $\mathrm{T}$ cell counts showed - similar to T helper cells - an intermediate peak during the 1st year that is slightly delayed (fig. 3). This result was also consistently found in all publications included.

B cells had smaller counts than T cells, but the kinetics was similar (fig. 4). This is consistently found in nearly all included publications.

The time course of NK cell counts obviously differed from that of the other lymphocytes. From birth on, there is a decreasing number of NK cells in the peripheral blood (fig. 5). However, this tendency could not be recognized in all publications. Frequently, NK cells are reported to have smaller counts.

\section{Discussion}

Cytometric analysis is an ideal tool for immunophenotyping, especially in children, for a multitude of reasons. It is a highthroughput technology that allows the rapid and accurate quantitation of even minute cell subsets such as stem or progenitor cells [53] in a few seconds to minutes by measuring tens of thousands to millions of cells. By measuring multiple colors it is easily feasible to detect simultaneously different epitopes on the same cell and thereby enabling its precise phenotyping.

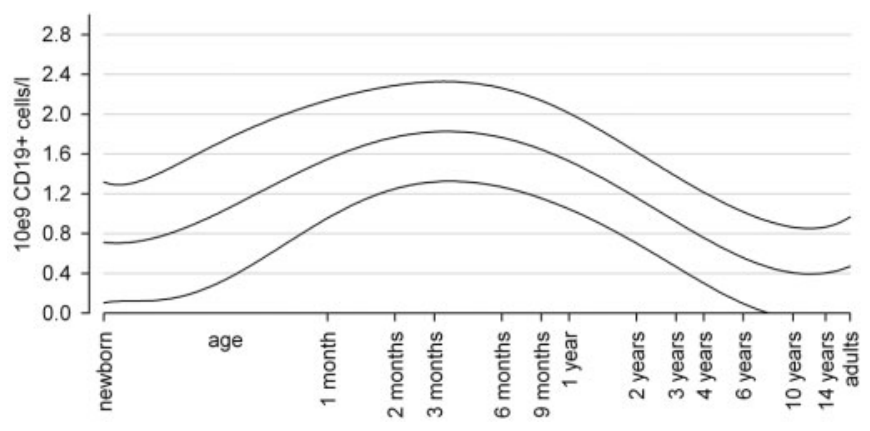

Fig. 4. Number of B cells (CD19+) in the peripheral blood of children from birth to adolescence. Data represent mean and + or - 1 SD. Calculation was based on 6 publications [36, 38-41] and is in accordance with 7 available papers presenting median and percentiles [42, 43, 45-48, 51].

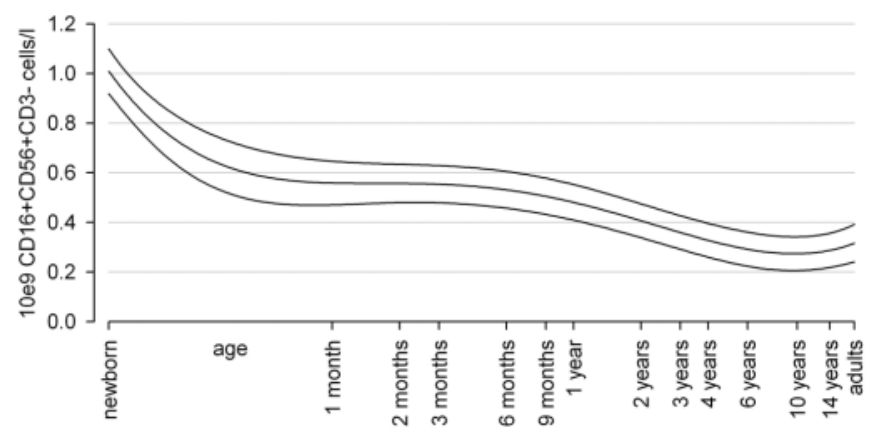

Fig. 5. NK cell count (CD3- CD16+ CD56+) in the peripheral blood of children from birth to adolescence. Data represent mean and + or $-1 \mathrm{SD}$. Calculation was based on 2 publications $[40,41]$ and is in accordance with 4 available papers presenting median and percentiles [42, 46-48].

Present technologies allow already to measure 6 colors for routine immunophenotyping and future developments may push this even forward to 17 or more colors [54,55] by applying sophisticated technology and novel fluorescent colors derived from nanotechnology $[8,56]$. There are two additional effects of multiplexed cell analysis:

- The required blood volume for diagnosis is drastically reduced. This is important for children, in particular in critically ill neonates. Progress in instrument and computer development [57] in the future will enable to even more reduce the required sample volume by performing cytometric analysis on the slide in specially designed microscopes $[58,59]$ that may be substantially cheaper then present instruments [60].

- The complex data pattern that results from the multiplexed measurements will allow to perform computer-aided systemic analysis [61] that may lead to improved risk assessment and hopefully to individualized medicine $[8,62]$.

Nevertheless, all these multiparameteric investigations require reliable normal values that represent inconspicuous findings 
in children without diseases. Our data show that meanwhile flow cytometric data are to a high degree independent of the technological platforms, selected antibodies, or laboratory protocols, when sticking consequently to validated protocols for clinical laboratory diagnostics. Furthermore, this allows merging data and findings out of several studies into one data set as a base for decision making. The high stability must not be true under all conditions. In fact, in immunodeficiencies most detection systems (labeling, instrument, analysis) must be validated under conditions representing realistic symptoms of such diseases. But in healthy persons this aspect is less critical. Time courses of the investigated cell populations underline the necessity to compare flow cytometric diagnostic findings strictly with age-related normal values. Without consideration of changes in early childhood, misinterpretation and misleading diagnostic reports may be generated.

\section{Conclusion}

Development-related alterations of lymphocyte subset counts in children could be extracted from the pre-existing papers for diagnostic use. These results were mostly independent of gender, ethnic factors, procedure of sample collection, anticoagulation, pre-analytical procedures, time to workbench, applied method for immunophenotyping, staining procedure, selected monoclonal antibodies, technical devices, and software products.

Our data indicate that previous normal values are not sufficiently precise for the interpretation of lymphocyte subsets in children. Mainly during the 1st year of life, count and subset distribution of lymphocytes is different from that of adults. Therefore, a close meshed data set for normal values is required to guarantee adequate diagnostic interpretation.

\section{References}

$>1$ Ahmad E, Kingma DW, Jaffe ES, Schrager JA, Janik J, Wilson W, Stetler-Stevenson M: Flow cytometric immunophenotypic profiles of mature gamma delta T-cell malignancies involving peripheral blood and bone marrow. Cytometry B Clin Cytom 2005;67B:6-12.

2 Ashman M, Sachdeva N, Davila L, Scott G, Mitchell C, Cintron L, Rathore M, Asthana D: Influence of 4- and 6-color flow cytometers and acquisition/analysis softwares on the determination of lymphocyte subsets in HIV infection. Cytometry B Clin Cytom 2007:DOI 10.1002/cyto.b.20178.

$\checkmark 3$ Brando B, Gatti A, Chianese R, Gratama JW: Twenty years of external quality assurance in clinical cell analysis - a tribute to Jean-Luc D'Hautcourt. Cytometry B Clin Cytom 2007;72B:2-7.

4 Laffers W, Mittag A, Lenz D, Tárnok A, Gerstner $\mathrm{AO}$ : Iterative restaining as a pivotal tool for $\mathrm{n}$-color immunophenotyping by slide-based cytometry. Cytometry A 2006;69A:127-130.

5 Qadir M, Barcos M, Stewart CC, Sait SN, Ford LA. Baer MR: Routine immunophenotyping in acute leukemia: Role in lineage assignment and reassignment. Cytometry B Clin Cytom 2006;70B:329-334.

$\checkmark 6$ Smith PA, Kohli LM, Wood KL, Hage CA, Twigg HL, Knox KS: Cytometric analysis of BAL T cells labeled with a standardized antibody cocktail correlates with immunohistochemical staining. Cytometry B Clin Cytom 2006;70B:170-178.

7 Liu Z, Hultin LE, Cumberlan WG, Hultin P, Schmid I, Matud JL, Detels R, Giorgi JV: Elevated relative fluorescence intensity of CD38 antigen expression on $\mathrm{CD} 8+\mathrm{T}$ cells is a marker of poor prognosis in HIV infection: results of 6 years of followup. Cytometry 1996;26:1-7.

8 Bocsi J, Mittag A, Sack U, Gerstner AO, Barten MJ, Tárnok A: Novel aspects of systems biology and clinical cytomics. Cytometry A 2006;69A: 105-108.

9 Brawura-Biskupski-Samaha R, Grzela T: Autoimmune lymphoproliferative syndrome-impaired regulation of the immune response by impaired induction of apoptosis. Transfus Med Hemother 2006;33: 71-79.
10 Seipp MT, Erali M, Wies RL, Wittwer C: HLA-B27 typing: evaluation of an allele-specific PCR melting assay and two flow cytometric antigen assays. Cytometry B Clin Cytom 2005;63B:10-15.

11 Stahl D: Current concepts on immune regulation: Impact on scientific and clinical aspects of immunohematology. Transfus Med Hemother 2005;32: 293-295.

12 Tárnok A, Valet GK, Emmrich F: Systems biology and clinical cytomics: the 10th Leipziger Workshop and the 3rd International Workshop on SlideBased Cytometry, Leipzig, Germany, April 2005. Cytometry A 2006;69A:36-40.

13 Ebo DG, Hagendorens MM, Bridts CH, Schuerweg AJ, De Clerck LS, Stevens WJ: Flow cytometric analysis of in vitro activated basophils, specific IgE and skin tests in the diagnosis of pollen-associated food allergy. Cytometry B Clin Cytom 2005;64B: 28-33.

14 Milovanova TN: Comparative analysis between CFSE flow cytometric and tritiated thymidine incorporation tests for beryllium sensitivity. Cytometry B Clin Cytom 2007:DOI 10.1002/cyto.b.20166.

15 Liu J, Roederer M: Differential susceptibility of leukocyte subsets to cytotoxic T cell killing: Implications for HIV immunopathogenesis. Cytometry A 2007;71A:94-104.

16 Gille C, Orlikowsky TW: Flow cytometric methods in the detection of neonatal infection. Transfus Med Hemother 2007;34(3):157-163.

17 Hamurcu Z, Demirtas H, Kumandas S: Flow cytometric comparison of RNA content in peripheral blood mononuclear cells of Down syndrome patients and control individuals. Cytometry B Clin Cytom 2006;70B:24-28.

18 Rockenbauer E, Petersen K, Vogel U, Bolund L, Kolvraa S, Nielsen KV, Nexo BA: SNP genotyping using microsphere-linked PNA and flow cytometric detection. Cytometry A 2005;64A:80-86.

19 Shim YK, Vogt RF, Middleton D, Abbasi F, Slade B, Lee KY, Marti GE: Prevalence and natural history of monoclonal and polyclonal B-cell lymphocytosis in a residential adult population. Cytometry B Clin Cytom 2007:DOI 10.1002/cyto.b.20174.

20 Habib LK, Finn WG: Unsupervised immunophenotypic profiling of chronic lymphocytic leukemia. Cytometry B Clin Cytom 2006;70B:124-135.
1 Lamb LS Jr, Neuberg R, Welsh J, Best R, StetlerStevenson M, Sorrell A: T-cell lymphoblastic leukemia/lymphoma syndrome with eosinophilia and acute myeloid leukemia. Cytometry B Clin Cytom 2005;65B:37-41.

22 Langebrake C, Brinkmann I, Teigler-Schlegel A, Creutzig U, Griesinger F, Puhlmann U, Reinhard D: Immunophenotypic differences between diagnosis and relapse in childhood AML: Implications for MRD monitoring. Cytometry B Clin Cytom 2005; 63B:1-9.

23 Shankey TV, Forman M, Scibelli P, Cobb J, Smith CM, Mills R, Holdaway K, Bernal-Hoyos E, Van Der HM, Popma J, Keeney M: An optimized whole blood method for flow cytometric measurement of ZAP-70 protein expression in chronic lymphocytic leukemia. Cytometry B Clin Cytom 2006;70B: 259-269.

24 Sutherland DR, Kuek N, Davidson J, Barth D, Chang H, Yeo E, Bamford S, Chin-Yee I, Keeney M: Diagnosing PNH with FLAER and multiparameter flow cytometry. Cytometry B Clin Cytom 2007:DOI 10.1002/cyto.b.20151.

25 Lina G, Cozon G, Ferrandiz J, Greenland T, Vandenesch F, Etienne J: Detection of staphylococcal superantigenic toxins by a CD69-specific cytofluorimetric assay measuring T-cell activation. J Clin Microbiol 1998;36:1042-1045.

26 Reichardt P, Lehmann I, Sierig G, Borte M: Analysis of T-cell receptor V-beta 2 in peripheral blood lymphocytes as a diagnostic marker for Kawasaki disease. Infection 2002;30:360-364.

27 Barz D: Perinatal transfusion medicine - immunological aspects. Transfus Med Hemother 2006;33: 473-473.

28 Tonn T, Seifried E: Natural killer cells for the treatment of malignancies. Transfus Med Hemother 2006;33:144-149.

29 Karger R, Weber C, Schmidt J, Kretschmer V: Immunomodulatory effects of non-leukocyte-depleted and leukocyte-depleted autologous blood Transfus Med Hemother 2006;33:302-306.

30 Cascalho M, Platt JL: B cells and B cell products helping to restore cellular immunity? Transfus Med Hemother 2006;33:45-49. 
31 Sack U, Rothe G, Barlage S, Gruber R, Kabelitz D, Kleine TO, Lun A, Renz H, Ruf A, Schmitz G: Flow cytometry in clinical diagnostics. J Lab Med 2000;24:277-297.

-32 Tárnok A, Bocsi J, Lenz D, Janousek J: Protein losing enteropathy after Fontan surgery - clinical and diagnostical aspects. Transfus Med Hemother 2007; 34(3):164-167.

33 Lenz D, Barten MJ, Hiller S, Tárnok A, Sack U: Regenerative and predictive medicine of cardiovascular disease: the 9th Leipziger Workshop and the 2nd International Workshop on slide based cytometry. Cytometry A 2005;64A:110-4.

-34 Bocsi J, Lenz D, Sauer U, Wild L, Hess J, Schneider P, Bocsi J, Hambsch J, Schranz D Tárnok A: Inflammation and immune suppression following protein losing enteropathy after Fontan surgery detected by cytomics. Transfus Med Hemother 2007; 34(3):168-175.

35 Sack U, Tárnok A, Rothe G (Hrsg): Zelluläre Diagnostik. Basel, Karger, 2006.

36 Hicks MJ, Jones JF, Minnich LL, Weigle KA, Thies AC, Layton JM: Age-related changes in T- and B lymphocyte subpopulations in the peripheral blood Arch Pathol Lab Med 1983;107:518-523.

-37 Yanase Y, Tango T, Okumura K, Tada T, Kawasaki T: Lymphocyte subsets identified by monoclonal antibodies in healthy children. Pediatr Res 1986;20: 1147-1151.

38 Babcock GF, Taylor AF, Hynd BA, Sramkoski RM, Alexander JW: Flow cytometric analysis of lymphocyte subset phenotypes comparing normal children and adults. Diagn Clin Immunol 1987;5:175-179.

>39 Wiener D, Shah S, Malone J, Lowell N, Lowitt S, Rowlands DT Jr: Multiparametric analysis of peripheral blood in the normal pediatric population by flow cytometry. J Clin Lab Anal 1990:4:175-179.

40 Beck R Lam-Po-Tang PR: Comparison of cord blood and adult blood lymphocyte normal ranges: a possible explanation for decreased severity of graft versus host disease after cord blood transplantation. Immunol Cell Biol 1994;72:440-444.

41 Shahabuddin S, Al Ayed I, Gad El-Rab MO, Qureshi MI: Age-related changes in blood lymphocyte subsets of Saudi Arabian healthy children. Clin Diagn Lab Immunol 1998;5:632-635.
42 Erkeller-Yuksel FM, Deneys V, Yuksel B, Hannet I, Hulstaert F, Hamilton C, Mackinnon H, Stokes LT, Munhyeshuli V, Vanlangendonck F, et al: Age-related changes in human blood lymphocyte subpopulations. J Pediatr 1992;120:216-222.

43 Heldrup J, Kalm O, Prellner K: Blood T and B lym phocyte subpopulations in healthy infants and children. Acta Paediatr 1992;81:125-132.

44 Denny T, Yogev R, Gelman R, Skuza C, Oleske J, Chadwick E, Cheng SC, Connor E: Lymphocyte subsets in healthy children during the first 5 years of life. JAMA 1992;267:1484-1488.

45 Kotylo PK, Fineberg NS, Freeman KS, Redmond NL, Charland C: Reference ranges for lymphocyte subsets in pediatric patients. Am J Clin Pathol 1993;100:111-115.

46 Hulstaert F, Hannet I, Deneys V, Munhyeshuli V, Reichert T, De Bruyere M, Strauss K: Age-related changes in human blood lymphocyte subpopulations. II. Varying kinetics of percentage and absolute count measurements. Clin Immunol Immunopathol 1994;70:152-158.

47 Comans-Bitter WM, de Groot R, van den Beemd R, Neijens HJ, Hop WC, Groeneveld K, Hooijkaas $\mathrm{H}$, Van Dongen JJ: Immunophenotyping of blood lymphocytes in childhood. Reference values for lymphocyte subpopulations. J Pediatr 1997;130: 388-393.

48 O'Gorman MR, Millard DD, Lowder JN, Yogev R: Lymphocyte subpopulations in healthy 1-3-day-old infants. Cytometry 1998;34:235-241.

49 Likanonsakul S, Wasi C, Thepthai C, Sutthent R, Louisirirotchanakul S, Chearskul S, Vanprapa N, Lebnark T: The reference range of $\mathrm{CD} 4+$ and CD8+ T-lymphocytes in healthy non-infected infants born to HIV-1 seropositive mothers; a preliminary study at Siriraj Hospital. Southeast Asian J Trop Med Public Health 1998;29:453-463.

50 Lisse IM, Aaby P, Whittle H, Jensen H, Engelmann M, Christensen LB: T-lymphocyte subsets in West African children: impact of age, sex, and season. J Pediatr 1997;130:77-85.

51 Robinson M, O'Donohoe J, Dadian G, Wankowicz A, Barltrop D, Hobbs JR: An analysis of the normal ranges of lymphocyte subpopulations in children aged 5-13 years. Eur J Pediatr 1996;155: 535-539.
52 The European Collaborative Study: Age-related standards for T lymphocyte subsets based on uninfected children born to human immunodeficiency virus 1-infected women. Pediatr Infect Dis J 1992; 11:1018-1026.

53 Kamprad M, Kindler S, Schuetze N, Emmrich F: Flow cytometric immunophenotyping of umbilical cord and peripheral blood haematopoietic progenitor cells by different CD34 epitopes, CD133, P-glycoprotein expression and rhodamine-123 efflux. Transfus Med Hemother 2007;34(3):195-203.

54 Perfetto SP, Chattopadhyay PK, Roederer M: Seventeen-colour flow cytometry: unravelling the immune system. Nat Rev Immunol 2004;4:648-655.

55 Mittag A, Lenz D, Gerstner AO, Tárnok A: Hyperchromatic cytometry principles for cytomics using slide based cytometry. Cytometry A 2006;69A(7): 691-703.

56 Chattopadhyay PK, Price DA, Harper TF, Betts MR, Yu J, Gostick E, Perfetto SP, Goepfert P, Koup RA, De Rosa SC, Bruchez MP, Roederer M: Quantum dot semiconductor nanocrystals for immunophenotyping by polychromatic flow cytometry. Nat Med 2006;12(8):972-7.

57 Parks DR, Roederer M, Moore WA: A new 'Logicle' display method avoids deceptive effects of logarithmic scaling for low signals and compensated data. Cytometry A 2006;69A(6):541-51.

58 Tárnok A: Slide-based cytometry for cytomics - a minireview. Cytometry A 2006;69A:555-562.

\$5 Laffers W, Schlenkhoff C, Pieper K, Mittag A, Tárnok A, Gerstner AOH: Concepts for absolute immunophenosubtyping by slide-based cytometry. Transfus Med Hemother 2007;34(3):188-194.

60 Shapiro HM, Perlmutter NG: Personal cytometers: slow flow or no flow? Cytometry A 2006;69A(7): 620-30.

61 Tárnok A, Bocsi J, Brockhoff G: Cytomics - importance of multimodal analysis of cell function and proliferation in oncology. Cell Prolif 2006;39(6): 495-505.

62 Valet G: Human cytome project, cytomics, and systems biology: the incentive for new horizons in cytometry. Cytometry A 2005;64A(1):1-2. 